\title{
Processing Yield from Parchment Coffee Demucilaged Mechanically and by Natural Fermentation
}

\author{
D. S. Boyce

\section{INTRODUCTION}

With the advent of intense and modern methods of coffee-processing more and more attention has been given to methods which will increase the output of dried parchment per acre, or the output of a given farm in order to reduce unit costs. The more obvious methods of increasing production are, of course, the introduction of higher yielding varieties, a high level of fertilization, and pest control. It was, however, generally considered that the processing of the coffee cherry to dry parchment was only important insofar as the quality of the dried parchment was concerned; however, studies in various parts of the world have indicated that one particular aspect of the processing operation may have a marked effect on the actual yield of dried parchment.

This aspect is the removal of the layer of mucilage, the mesocarp, which surrounds the parchment shell, the spermodern, after it has been separated by pulping from the skin and flesh, the epidermis and pericarp, surrounding it. This mucilage must be removed before the parchment can be dried as it is highly hygroscopic and, if the parchment were dried without removing it, moisture would be rapidly reabsorbed and the parchment would spoil $(5)^{2}$. Several methods of removing this mucilage are available; however, the most common method in Puerto Rico and elsewhere is by natural fermentation.

But it has been reported that alternative methods of removing the mucilage $(1,5,7)$ result in a considerably higher yield of dry matter. It was therefore considered desirable to initiate a study to see whether significant increases in production could be realized in Puerto Rico if an alternative method of removing the mucilage from parchment coffee were adopted.

For reasons which will be apparent from the Review of Literature it was considered that the most suitable and most rapid way to demucilage parchment coffee, other than by natural fermentation, is by using a mechanical demucilager. For this reason a comparative study of the yield of dry matter from parchment coffee which had been submitted to natural fermentation and parchment coffee which had been mechanically demucilaged was undertaken.

1 Assistant Professor, Department of Agricultural Engineering, College of Agriculture and Mechanic Arts, Mayagüez, P.R.

Italic numbers in parentheses refer to Literature Cited, p. 341. 


\section{REVIEW OF LITERATURE}

Four general methods are used to demucilage parchment coffee (B): 1 , By natural fermentation; 2, digestion by artificial enzymes; 3 , by alkali hydrolysis; and 4, mechanically, where the mucilage is rubbed off by means of friction or by high-pressure water jets. Natural fermentation has the outstanding advantage that, provided it will destroy the mucilage in a reasonable time, no equipment is necessary, nor do any materials need to be purchased. The disadvantages of using natural fermentation are: 1 , That under certain conditions it may take a very long time, up to 100 hours; 2 , this will involve the provision of a large number of fermentation tanks and greatly contribute to the capital cost of the installation. Another disadvantage believed to be unfavorably associated with natural fermentation and which has been already referred to, is that a considerable loss of weight occurs during the process. Jones and Bayer (5) stated that this may be as much as 3.9 percent. Banel (1) reported that, if natural fermentation were eliminated, the average saving in weight would be about 3 percent. Wellman (7) reported a similar value and stated further that, under natural fermentation, coffee beans lose weight every hour.

The disadvantages of using enzyme digestion for removing the mucilage layer are: First, the cost of the pectic enzymes, the active material used, and secondly, that if economic quantities of this material are to be used, a period of 5 to 10 hours is required for demucilaging. The latter is unsatisfactory from a practical point of view, as coffee cherries are generally pulped in the evening and, unless the parchment is to be washed during the night, it would have to be left until the following morning. It therefore follows that, as there is a period of 12 to 16 hours between pulping and washing, and if demucilaging can be carried out by natural fermentation during this period, it would be wasteful and unnecessary to resort to the use of pectic enzymes.

The use of alkali hydrolysis for breaking down the mucilage has the advantage that, provided a 6-percent solution of sodium hydroxide is used, complete mucilaging occurs in about 1 minute ( $(3)$. An outstanding disadvantage associated with this and also with enzyme digestion is that it is not only necessary to purchase the materials, but that these must also be diluted to exact limits before they are used so as to achieve the most economic use of materials. This requires a degree of technical skill which may not always be available under practical conditions. In addition, strong alkali is very corrosive and requires extremely careful handling. Wellman (7) reported that in replicated cup-testing by commercial tasters chemically washed coffee, demucilaged by alkali hydrolysis, proved equal to coffee processed by the natural method and even slightly superior to coffee processed by the use of enzymes. 
Mechanical devices used to demucilage coffee work on the principle that the friction between the parchment and some moving part removes the mucilage which is then carried away by a generous flow of water. Various types of machines are available as described by Fukunaga ( 3 ). Wellman (7) reported that coffee cleaned of mucilage by friction and water seemed to have about the same taste as the standard fermentation-cleaned coffee. The main disadvantage associated with mechanically demucilaging is that an additional machine must be purchased and operated. It should be noted that in reviewing the various reports of work on this subject no details were available on the conditions under which differences in yield were obtained. Consequently it was useful to undertake this study under conditions likely to be encountered in Puerto Rico.

\section{EXPERIMENTAL PROCEDURE}

This project was intended to provide information on both the yield of dry matter and concerning the relationship between temperature and the rate of natural fermentation; however, no clear relationship between the fermentation rate and temperature was evident when the data were subjected to analysis.

Parchment coffee may be subjected to natural fermentation in two ways. It may be fermented as a wet sticky mass with the water drained away, or fermentation may take place under water. Haarer (4) stated definitely that coffee parchment should not be fermented in a tank of water, but should be left to lie as a sticky mass with the water drained away. Fukunaga (3), on the other hand, stated that fermentation may take place either in or out of water though in water it takes much longer. It is more or less the universal practice in Puerto Rico to carry out the natural fermentation of parchment coffee without water and consequently this method of fermenting parchment was used for this study.

A constant-temperature chamber was constructed to subject samples of freshly pulped parchment to natural fermentation under controlled conditions. Electrical heating elements suitably shielded and controlled by a thermostat, with a sensing element located in the geometric center of the chamber, provided temperature control to within $1^{\circ} \mathrm{F}$. The room was always maintained at a considerably lower temperature by airconditioning. The samples to be fermented were placed in small mesh plastic baskets which, in turn, were placed in glass beakers. To prevent the samples drying out a little water was placed in each beaker below the level of the bottom of the basket, while the top of the basket was covered with a wad of wet cloth.

A small-batch mechanical demucilager was constructed using a 1-gallon cylindrical oilcan. A removable basket-liner of coarse screen was placed 
inside the can, and a rectangular beater made of 3/16-inch-square key stock, driven by a $1 / 2$-hp. electric drill mounted on a vertical bracket, demucilaged the parchment by rubbing it in water against the screen. The clearance between the beater and the screen was a little greater than the average thickness of the parchment. Water was allowed to flow continuously into the top of the can and out through the bottom in order to remove the mucilage which had been separated from the parchment by the rotating beater. This device worked most satisfactorily when only a very little water was allowed to flow through the can. When the parchment had been completely demucilaged a generous flow of water was used to remove the mucilage from the container.

Each of the samples of fresh coffee cherries was treated in the following way: The sample was pulped and two subsamples were weighed and placed in the mesh baskets in beakers to be placed in the fermentation chamber so that spontaneous natural fermentation of the mucilage would occur. The remainder of the parchment was weighed, then completely demucilaged mechanically. The weight of mucilage removed was determined. The mechanically demucilaged parchment was divided into four subsamples two of which were placed in fermentation baskets and beakers and put in the fermentation chamber at the same time as the two subsamples of undemucilaged parchment were being subjected to natural fermentation. The remaining two subsamples were placed in an oven and dried to constant weight at about $135^{\circ} \mathrm{F}$. It was found that this took 48 hours.

The subsamples were removed from the fermentation chamber before it was estimated that fermentation of the mucilage had been completed. The subsamples were then washed, after which the amount of mucilage broken down by natural fermentation was determined, as well as any change in weight of the subsamples which had previously been demucilaged mechanically. These latter two subsamples were now placed in the oven and dried to constant weight. The subsamples of partly fermented parchment were then mechanically demucilaged to remove the remainder of the mucilage. The final weight of the naturally fermented and mechanically demucilaged subsamples was determined and the subsamples were then oven-dried to constant weight. All the above data were collected from 15 samples of freshly harvested coffee cherries grown at both high and low elevation. The temperature of the fermentation chamber varied from $74^{\circ}$ to $96^{\circ} \mathrm{F}$.

\section{RESULTS AND DISCUSSION}

All the results were expressed for convenience in terms of yield in grams from $100 \mathrm{gm}$. of unfermented parchment, which henceforth will be referred to as "UFP." The average amount of mucilage removed mechanically per $100 \mathrm{gm}$. UFP was $34.9 \mathrm{gm}$. The average yield of dry matter per $100 \mathrm{gm}$. 
UFP for each of the three treatments employed was as follows: 1, Mechanically demucilaged-oven dried, MD.OD.-30.38 gm.; 2, mechanically demucilaged, placed in the fermentation chamber, and then oven-dried, MD.FC.OD.-30.40 gm.; and 3, naturally fermented, mechanically demucilaged, and oven-dried, NF.MD.OD. $-27.74 \mathrm{gm}$.

The results were subjected to statistical analysis and as the material for each treatment was taken from the same sample of freshly picked cherries and the treatments were carried out simultaneously the differences between each of the treatments were considered. The analysis of variance of

TABLE 1.-The analysis of variance of the difference between the differences in yield of dry matter for $\$$ methods of preparing parchment coffee

\begin{tabular}{c|c|c|c|c|c}
\hline \multicolumn{1}{c|}{ Factor } & Sum of squares & $\begin{array}{c}\text { Degrees of } \\
\text { freedom }\end{array}$ & Variance & calculated & $\begin{array}{c}\text { F at 1-percent } \\
\text { level }\end{array}$ \\
\cline { 2 - 4 } Total & 136.95 & 44 & & & \\
Treatment & 64.57 & 2 & 32.29 & 18.77 & 5.15 \\
\cline { 2 - 5 } Error & 72.38 & 42 & 1.72 & & \\
\hline
\end{tabular}

TABLE 2.-Main differences between each of the 3 treatments and the difference between each, in grams

\begin{tabular}{l|c|c|c}
\hline \multicolumn{1}{c|}{ Samplet } & Mean difference & $\begin{array}{c}\text { Diference from } \\
\text { previous value }\end{array}$ & $\begin{array}{c}\text { Difference between } \\
\text { 1st and 3rd } \\
\text { treatments }\end{array}$ \\
\hline 1, MD.OD.-MD.FC.OD. & 0.49 & & \\
2, MD.FC.OD.-NF.MD.OD. & 2.66 & 2.17 & \\
3, MD.OD.-NF.MD.OD. & 3.28 & .62 & 2.79 \\
\hline
\end{tabular}

1 See text for explanation.

the difference between each of the three treatments is shown in table 1 . There was a very significant difference between the treatments as shown in table 2.

A difference between any treatment difference of $1.52 \mathrm{gm}$. is significant at the 5-percent level and of $2.80 \mathrm{gm}$. at the 1-percent level. Therefore there is no significant difference between parchment which had been prepared by mechanical demucilaging and immediately oven-dried and parchment treated in the same way, but held for a period of time at a temperature and under conditions where undemucilaged parchment would be subjected to spontaneous natural fermentation. There is, on the other hand, a significant difference at the 5-percent level between parchment subjected to mechanical demucilaging and parchment which has had some mucilage 
removed by natural fermentation, even though the samples were subjected otherwise to the same treatment. This would lead one to believe that the actual process of natural fermentation was associated with the loss of dry matter. The difference between the loss of weight of parchment processed by mechanical demucilaging and immediate oven-drying was virtually significant at the 1-percent level.

It should be noted that the differences shown are in yields of dry matter. If these are expressed in terms of parchment coffee at a moisture content of 12 percent, wet basis, they will be greater. The difference between 2, MD.FC.OD.-NF.MD.OD. being $3.20 \mathrm{gm}$. per $100 \mathrm{gm}$. UFP and between 3, MD.OD.-NF.MD.OD. being $3.72 \mathrm{gm}$. per $100 \mathrm{gm}$. UFP. The latter agrees very closely with values determined by other investigations previously referred to. It should also be expected in practice, assuming that mechanical demucilaging was immediately followed by drying, that the yield would be somewhat higher, as in this study natural fermentation was not allowed to go to completion. The problem of whether or not mechanical demucilaging should be introduced as regular practice will depend on whether the additional yield of plus 3 percent of parchment would economically justify the cost of installing and operating a mechanical demucilager. It should be noted that the parchment subjected to mechanical demucilaging had a much better appearance, being much higher in color than the parchment subjected to natural fermentation which was yellowish in contrast.

Attempts were made to establish a correlation between either the duration of fermentation, the temperature at which it takes place, the quantity of mucilage broken down or the loss of dry matter of the parchment. In none of these cases could a correlation be established.

It was, however, apparent when plotting pairs of these variables on graph paper that many of the points fell in a markedly straight line, showing that the rate of fermentation increased with temperature and also that the amount of mucilage broken down was proportional to the time of fermentation; however, the remainder of the points on these graphs were most randomly scattered. One possible interpretation of this is that an agent the activities of which are particularly influenced by temperature and time, sometimes casually infected the unfermented parchment, thus initiating the breakdown of the mucilage; however, on occasion, another vector, the activities of which are more spontaneous and less influenced by temperature, infect the sample creating a rather conflicting pattern.

\section{SUMMARY}

1. It was confirmed that parchment coffee demucilaged mechanically gave a higher yield of dry matter than parchment coffee which had been 
subjected to natural fermentation in a moist atmosphere with the water drained away from it. This difference was very nearly significant at the 1-percent level.

2. It was found that the loss of weight was to a large extent associated with the fermentation process. As there was a significantly greater loss of weight at the 5-percent level between samples of parchment treated identically, except that the samples with the greatest yield of dry matter were subjected to mechanical demucilaging before being subjected to conditions where natural fermentation would take place.

3. The introduction of mechanical demucilaging would be dependent upon whether an increased yield exceeding 3 percent in the dried parchment coffee would justify the capital and operating costs of a mechanical demucilager.

4. No correlation was established between loss of dry matter during fermentation or the rate of breakdown of mucilage by natural fermentation and the temperature or duration of natural fermentation. It could be supposed that the agents responsible for the natural fermentation casually infect the parchment and that some such infections are much influenced by time or temperature, while others are more spontaneous and less influenced by these factors.

\section{RESUMEN}

1. Se confirmó que el rendimiento de materia seca del café desmucilaginado por medios mecánicos fue mayor que el del café sometido al proceso de fermentación natural en un ambiente húmedo y permitiendo que el agua escurriera. Esta diferencia fue prácticamente significativa al nivel del uno por ciento.

2. Se encontró que la pérdida de peso obedecía mayormente al proceso de fermentación, habiéndose registrado una pérdida significativamente mayor al nivel del 5 por ciento entre muestras de café pergamino tratadas idénticamente, a excepción de que las muestras que rindieron la mayor cantidad de materia seca fueron desmucilaginadas mecánicamente antes de exponerse a las condiciones de fermentación natural.

3. La ventaja de adoptar la desmucilaginación mecánica dependería de si un aumento en rendimiento de más del 3 por ciento del pergamino seco pudiera justificar el capital invertido y la operación del equipo necesario.

4. No pudo establecerse correlación alguna entre la pérdida de materia seca durante la fermentación o la rapidez de descomposición del mucílago y la temperatura o la duración de la fermentación natural. Podría suponerse que los agentes responsables de la fermentación natural contaminan el pergamino en forma fortuita y que determinados agentes son más afectados que otros por la temperatura o la duración del proceso. 


\section{LITERATURE CITED}

1. Bannel, Marshal, A., New green coffee processing method reduces shrinkage and weight loss, Tea \& Coffee Trade J. 106 (3) 34-5, 1954.

2. Dewey, Richard E., The fermentation of washed green coffee, Tea \& Coffee Trade $J .111$ (2) $14,1956$.

3. Fukunaga, Edward T., A New Mechanical Coffee Demucilaging Machine, Hawaii Agr. Exp. Sta., Bul. 115, December 1957.

4. Haarer, A. E., Modern coffee production, Leonard Hill (Books) Ltd., London, England, 1956.

5. Jones, M. A., and Bayer, J. J., A Machine for the Chemical Removal of Mucilage from Freshly Pulped Coffee, Inst. Agrop. Nac. de Guatemala (mimeograph) 1954.

6. Johnson, W. R., and Foote, H. E., A new coffee process developed, Tea \& Coffee Trade J. 101 (6) 13, 1951.

7. Wellman, Frederick L., Coffee, Leonard Hill (Books) Ltd., London, England, 1961. 